\title{
LARGE-SCALE MINING IN LUZON, PHILIPPINES: ASSESSMENT OF THE MANDATED SOCIAL RESPONSIBILITY TO THEIR HOST COMMUNITIES
}

\author{
Jackie Lou O. Raborar ${ }^{1}$ \\ Ph.D. student, Commerce, The Graduate School, \\ University of Santo Tomas, Manila, Philippines. \\ (Email: jackielou.raborar.gs@ust.edu.ph) \\ Elizabeth O. Recio, Ph.D. ${ }^{2}$ \\ Professorial Lecturer, The Graduate School, \\ University of Santo Tomas, Manila, Philippines. \\ (Email: eo_recio@hotmail.com)
}

Received date: 30-07-2019

Revised date: $19-08-2019$

Accepted date: 22-08-2019

Published date: 11-09-2019

To cite this document: Raborar, J. L. O. \& Recio, E. O. (2019). Large-Scale Mining in Luzon Philippines: Assessment of the Mandated Social Responsibility to their Host Communities. International Journal of Modern Trends in Social Sciences, 2(9), 56-76.

DOI: $10.35631 /$ IJMTSS.29006

\begin{abstract}
In this global market, the demand and competition for mining products are very high. However, the adverse impact on the environment and society has become very prevalent. In the World Bank report, there are social issues that still unaddressed; there is the issue of how the benefits are allocated within the host communities, and it's a challenge to mining companies to behave responsibly especially with their relationship to the host communities. United Nations has committed to "leaving no one behind" in an effort to help countries promote inclusive growth and achieve the Sustainable Development Goals (SDGs). The Philippine government, through the Department of Environment and Natural Resources (DENR), has established the Republic Act No. 7942, 'or the Philippine Mining Act of 1995. The Development of Mining Communities has been emphasized in Chapter XIV Section 134$136 F$ of its Consolidated Administrative Order 2010-21. The Social Development and Management Program (SDMP) is mandated to be implemented by all operating mining/quarrying companies to support the education, health, social, cultural and economic aspects in the host communities. Since its implementation in 2011, it was noted that there are inconsistencies in the implementation of the Program. Thus, this research provided the necessary framework and recommendations to help just completed Programs and eventually improve the existing implementation of SDMP of mining companies. The concurrent triangulation mixed-methods research design was utilized wherein both the qualitative and quantitative approaches were simultaneously analyzed. Survey questionnaires were administered to an estimated 376 respondents from the host communities during site visits. In addition, interview and FGD were conducted to the various community representatives of the
\end{abstract}


same. The results are the basis of a policy framework to help improved and reach its objectives to create self-reliant and resources-based communities.

\author{
Keywords: Corporate Social Responsibility, Community Development, Sustainable \\ Development, Host Communities, Social Development, Mixed Method Design
}

\title{
Introduction
}

The mining industry is viewed as a major contributor to the country's fortune (Katrin \& Kehrbach, 2014), as it answers the increasing demands for mineral products and other major industries, like manufacturing, clinical, construction, and digital technology. Thus, the industry significantly contributes to the country's wealth generation.

In the case of the Philippines, the Philippine Mining Act (PMA) of 1995 allows for local and foreign granting of mining contracts that enables them to explore, develop, and utilize mineral resources. The PMA of 1995 provides, among others, that it shall be the responsibility of the State to promote the rational exploration, development, utilization, and conservation of its mineral resources through the combined efforts of the government and the private sector in order to enhance national growth in a way that also effectively safeguards the environment and protects the rights of the affected communities.

In the context of the Philippine Constitution, Article XII, Section 16 of the Philippine Constitution: "Government-owned or controlled corporations may be created or established by special charters in the interest of the common good." Common good refers to the benefits of everyone, or as many philosophers have defined it, the good of the many and not the good of only one (Doing Good in Business Matters, 2007). However, the said industry is facing its biggest problem when it comes to adverse environmental and local community impacts. Mining is not and cannot be a sustainable activity, because its operation has a specific end. However, according to The International Council on Mining and Metals (ICCM, 2012) mining can significantly contribute to sustainable development if they can align their objectives to the values of the society in promoting socio-economic growth and development of the impacted communities (Pimentel, Gonzalez, and Barbosa, 2016).

People are expecting that mining companies can significantly alleviate them from the very high poverty incidence level that they are into. This is the common challenge not only in the Philippines, but also in the international community (Zhou, Guo, Liu, Wu \& Li, 2018). Farmers, fishermen, and the other significant sectors comprise the concentration of groups with the highest poverty incidence level, as consistently shown from 2006-2015 (www.psa.gov.ph, 2017). The said groups are mostly dependent on their primary livelihood, which are sourced from resources endemic in their areas and are thus the most affected by the impact of mining activities.

\section{Research Problem}

The main problem in the Philipines is how the government addresses the social issues facing mining companies in their host communities. Recognizing the utmost importance of the social acceptability that mining companies must fulfill (as part of the mandated requirements) before embarking on any mining/quarrying projects in the country, the national government, through the Mines and Geosciences Bureau, formulated the Social Development and Management Programs (SDMP) that are currently being implemented as mandated under the 
Consolidated Department of Environment and Natural Resources Administrative Order (CDAO) No. 2010-21, the Revised Implementing Rules and Regulations of Republic Act No. 7942, otherwise known as the Philippine Mining Act of 1995.

However, it was noted that there are inconsistencies in the implementation of the mandated Social Development and Management Programs (SDMPs) of mining companies in partnership and consultation with the community that affect the objective of the government to support the education, health, social, cultural and economic aspects in the host communities.

\section{Research Objectives}

In order to address the research problem, this study has the following objectives:

1. To determine the awareness of the communities about the Social Development and Management Programs of mining companies in terms of the following accredited programs/projects/activities under the CDAO-2010-21

1.1 Human Resources Development

1.2 Enterprise Development

1.3 Assistance to Infrastructure Development

1.4 Access to Education

1.5 Access to Health Services

1.6 Protections and Respect of Socio-Cultural Values

2. To measure the impact of Social Development and Management Programs to the following aspects:

2.1 Education

2.2 Health

2.3 Social and Cultural

2.4 Economic

3. To ascertain the sustainability of the Social Development and Management Programs of the mining companies in terms of:

3.1 Stakeholders Groups Relationship

3.2. Company Financial and Management Capacity

3.3 Compliance with the legal requirements

\section{Literature Review}

\section{Mining Industry in the Philippines}

The yearly Survey of the Philippine Business and Industry (ASPBI) released its latest 2015 Mining and Quarrying for All Establishments. The results showed that 228 establishments are involved in the mining and quarrying activities as part of the formal sector of the economy (Figure 1). The greater numbers of establishments are sand and gravel for about 60 or $26.30 \%$ in total; while second is gold, with $11.4 \%$ in total. Nickel ore mining, stone quarrying, clay and sand pits, for third and fourth places with 23 establishments (10.1\%) and 20 establishments (8.8\%), respectively (ASPI, 2015). Other industries with more than 10 establishments are as follows: Limestone quarrying, 19 establishments (8.3\%); Extraction of salt, 14 establishments $(6.1 \%)$; and provide activities for other mining and quarrying, 11 establishments $(4.8 \%)$. 


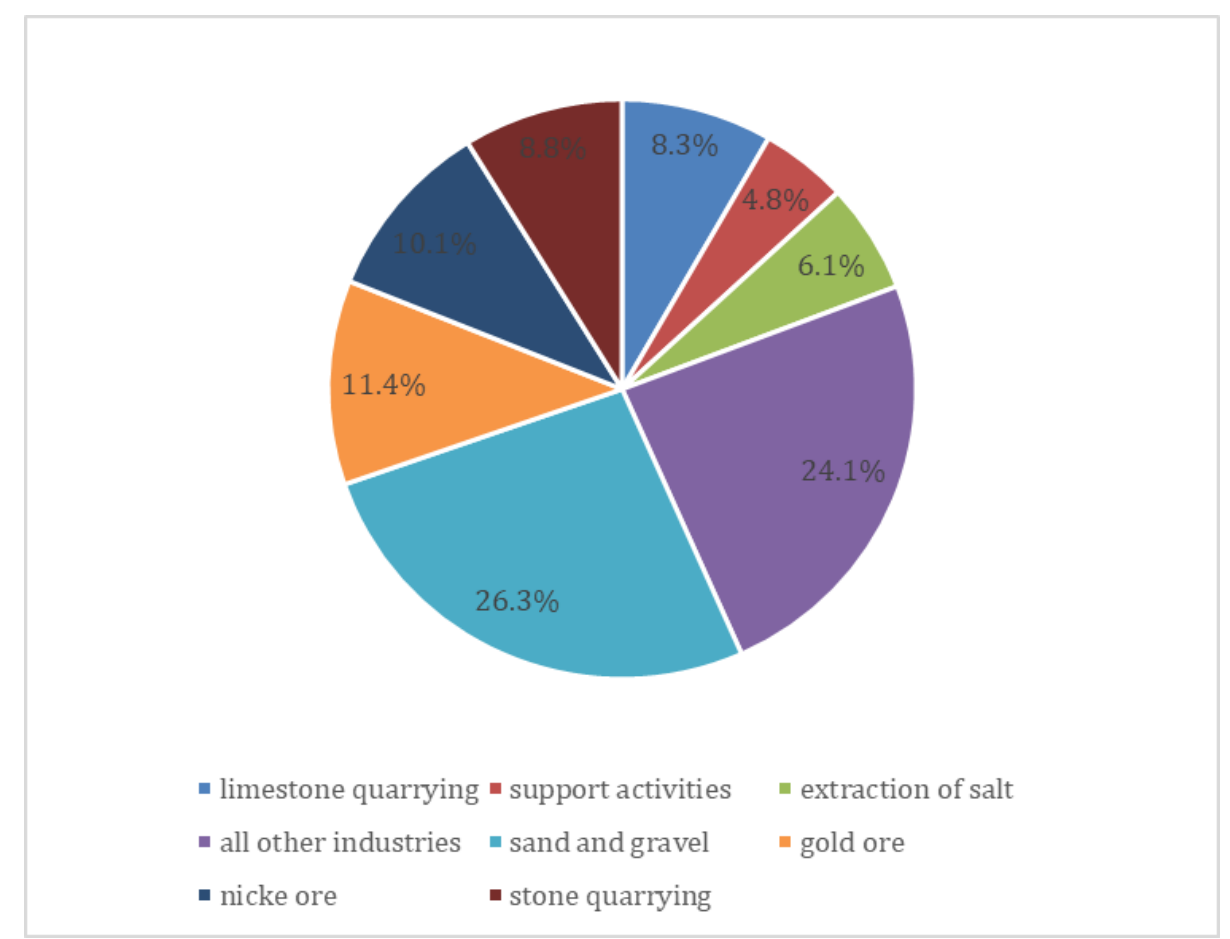

\section{Figure 1: The Distribution Percentage of all Mining and Quarrying Establishments by Industry Sub-Class in 2015. (ASPI, 2015)}

\section{Mining Law/Policies in the Philippines}

Mining companies, as stated in the law, must contribute to the growth of their affected host and neighbouring communities through the implementation of its Social Development and Management Program (SDMP).

The SDMP was formulated to fulfill the social obligations toward the development of communities that are affected by mining operations (PH-EITI, 2014). It aims to create responsible, self-reliant, and resource-based communities that are capable of developing, implementing, and managing their own development programs in a manner consistent with the principles of people empowerment and sustainable development (DENR: MGB).

With that, the Department was guided in the creation of the Program as stated in RA 7942 and its CDAO 2010-21, the SDMP is guided with the following mandatory requirements: Adherence to the Legal requirement under CDAO 2010-21, Section 134: Development of Mining Community, Mining Technology and Geosciences, and Institutionalization of Public Awareness and Education

a. The Contractor/Permit Holder/Lessee shall assist in the development of the host and neighbouring communities in accordance with its SDMP to promote the general welfare of the inhabitants living therein.

b. The Contractor/Permit Holder/Lessee shall develop a program for the advancement of mining technology and geosciences to build up resources and mineral discoveries, improve operational efficiency and resource recovery, and enhance environmental protection and mine safety;

c. The Contractor/Permit Holder/Lessee shall develop and institutionalize an Information, Education and Communication (IEC) Program for greater public awareness and understanding of responsible mining and geosciences; and 
d. The Contractor/Permit Holder/Lessee shall allot annually a minimum of one and a half percent $(1.50 \%)$ of the operating costs necessary to implement Subsections (a), (b) and (c) of this Section: Provided, That of this amount, $1.125 \%$ (75\% of $1.50 \%)$ shall be apportioned to implement the SDMP in Subsection (a) hereof, $0.150 \%$ (10\% of $1.50 \%$ ) for the implementation of Program for the Development of Mining Technology and Geosciences in Subsection (b) hereof and $0.225 \%$ (15\% of $1.50 \%$ ) for the implementation of IEC Program in Subsection (c) hereof: Provided, further, That any unspent amount and/or Mining and Geosciences (http://www.mgb.gov.ph/images/stories/CDAO-Final.pdf).

The Philippine Mining Act of 1995 is the foremost law in the country today when it comes to consideration of local government empowerment, respect and concern to the indigenous cultural communities, fair sharing of natural wealth benefits, sustainable development, globalization readiness, and the protection and preservation of the environment. It's a propeople and pro-environment policy that was the outcome of a deep analysis of the shortcomings and gaps of the previous laws to address the present needs. The governing principles of this law provide stringent adherence to the principle of people empowerment and sustainable development (MGB, 1995). Table 1 provides a summary of the mining laws and regulations in the country.

Table 1: The Development of Mining Laws and Regulations in the Philippines

\begin{tabular}{|c|c|c|}
\hline $\begin{array}{l}\text { REPUBLIC } \\
\text { ACT/DAO }\end{array}$ & LAW/ ORDER & CONTENT \\
\hline RA 7942 & $\begin{array}{c}\text { The Philippine Mining } \\
\text { Act of } 1995\end{array}$ & $\begin{array}{l}\text { States that it shall be the responsibility of the State } \\
\text { to promote their rational exploration, } \\
\text { development, utilization and conservation through } \\
\text { the combined efforts of government and the } \\
\text { private sector in order to enhance national growth } \\
\text { in a way that effectively safeguards the } \\
\text { environment and protect the rights of the affected } \\
\text { communities. The governing principle is } \\
\text { sustainable development (The Philippine Mining } \\
\text { Act of 1995). }\end{array}$ \\
\hline EO 79 & $\begin{array}{c}\text { Executive Order No. } \\
70\end{array}$ & $\begin{array}{l}\text { Former President Aquino on July 6, } 2012 \text { issued } \\
\text { an Executive Order no. } 79 \text { (EO 79) to harden the } \\
\text { protection of the environment, promote } \\
\text { responsible mining, equal share of natural wealth } \\
\text { benefits, transparency and accountability } \\
\text { (Raymundo, 2014). }\end{array}$ \\
\hline $\begin{array}{c}\text { DAO } 1996- \\
40\end{array}$ & $\begin{array}{l}\text { Revised Implementing } \\
\text { Rules and Regulations } \\
\text { of RA } 7942\end{array}$ & $\begin{array}{l}\text { Provides specific details for Chapter X, Section } \\
57-58 \text { of RA } 7942 \text { (Chapter XIV, Section 134- } \\
136 \text { ) }\end{array}$ \\
\hline $\begin{array}{c}\text { DAO } 2000- \\
99\end{array}$ & $\begin{array}{l}\text { Rules and Regulations } \\
\text { on the Implementation } \\
\text { of Social } \\
\text { Development and } \\
\text { Management Program } \\
\text { (SDMP) }\end{array}$ & $\begin{array}{l}\text { Added Sections 136A to 136-E the regulation and } \\
\text { guidelines for the implementation, approval, and } \\
\text { monitoring of Social Development and } \\
\text { Management Program }\end{array}$ \\
\hline
\end{tabular}




\begin{tabular}{|c|c|l|}
\hline $\begin{array}{c}\text { DAO 2010- } \\
13\end{array}$ & $\begin{array}{c}\text { Revised Implementing } \\
\text { Rules and Regulations } \\
\text { of RA 7942 }\end{array}$ & $\begin{array}{l}\text { Specifically, revised sec 134-136D of DAO 96-40. } \\
\text { The increase allotment from 1\% to } 1.5 \% . \\
\text { Provisions of the guidelines of P/P/As, requiring } \\
\text { of review and evaluation of SDMPs also } \\
\text { amendments of sec 137 for the guidelines } \\
\text { contribution to advancement of mining technology } \\
\text { and geosciences (DAO 2010-13) }\end{array}$ \\
\hline $\begin{array}{c}\text { DAO 2010- } \\
21\end{array}$ & $\begin{array}{c}\text { Consolidated } \\
\text { Implementing Rules } \\
\text { and Regulations of } \\
\text { RA 7942 }\end{array}$ & Consolidated the provisions of DAO 96-40 \\
\hline
\end{tabular}

\section{Community Development in the Mining Industry}

Community development refers to the plan of activities of the mining companies in partnership with the local communities to create positive social benefits, such as improvement of the quality of life that is also sustainable (Wilson, 2015). Community development is a people-centered practice in specific kinds of affinities between people (Westoby, 2014).

Community development approaches are recognized globally and are widely used in any discipline. Its interpretation has shown to be very complex, that policy makers, legislators and development experts have come up with its definition with prudence (Nwapi et al; 2017). Within the mining industry, community development is used to fulfill social obligations in communities located within the areas of the mining operations (Kemp, 2010; Nwapi, 2017). Development of the programs/projects/activities includes human development, networking, infrastructure development, health services, education support and protection and respect to cultural values of the affected communities (Kemp, 2010; Nwapi, 2014).

A significant element of community development within the mining sector is the participation of the community itself from the design and implementation of the development programs from the first stage up to the last part. (Nwapi, 2014). The efforts of empowering communities to participate in the development process are however essential for the objectives of CD to be realized (Nwapi, 2014).

\section{Sustainable Development and People Empowerment}

The United Nations Sustainable Development Goals 2030 is properly coined in the 2030 Agenda. The wide intentions are interrelated with each other but have specific sub-targets to be attained. The aggregate total number of aims is about 169. The SDGs incorporate a broader range of societal and economic development concerns that focus on poverty incidence, hunger, education, health, gender inequality, health and sanitation, among others. Mining companies have the most problems with human and the environment that the UN social development goal 2030 tries to address (Frazer, 2018). More sustainable outcome will be achieved if mining companies integrate their skills and knowledge in addressing those issues, these joint partnerships can improve stakeholders' relationship, it may reduce misunderstanding that affect the community and the mining companies (George, 2016 \& Fraser, 2018; Kemp \& Owen, 2013). A sound partnership between mining companies and the communities is the way in achieving mutual benefits. It is important to conclude that fruitful partnership with the communities should be based on the clear and honest communication, which builds trust (Zvarivadza, 2017). 
Sustainable Partnerships between mining companies and the communities

Zvarivadza (2017) the necessary elements for a sustainable agreement between mining companies and the communities.

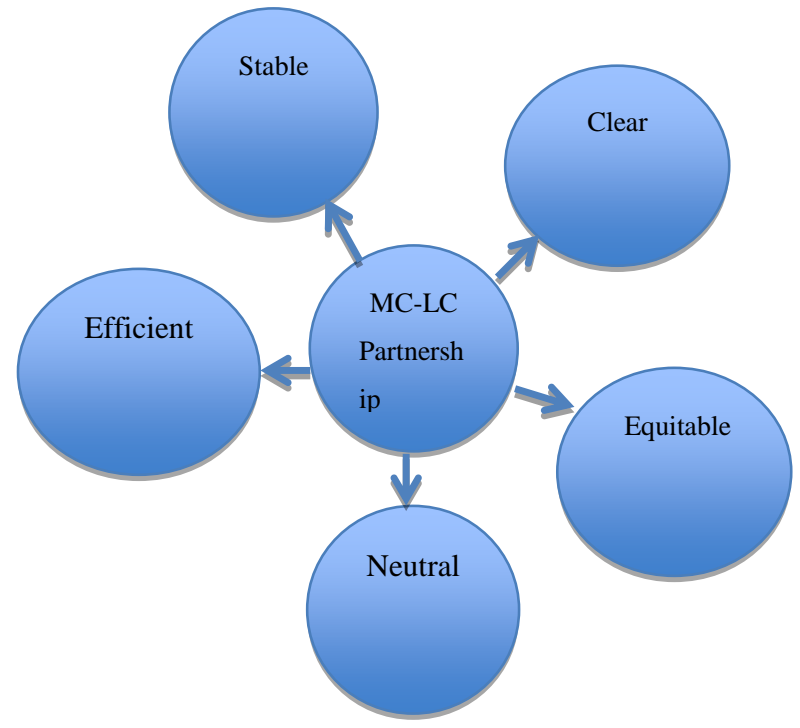

Figure 2: Wheel of Sustainable Development Partnership Agreement (Zvarivadza, 2017)

\section{Corporate Social Responsibility in the Mining Industry}

Corporate Social Responsibility (CSR) is often considered mandatory in the mining industry since its operation has a direct impact to the environment and local communities. The recognition toward CSR is increasing since it has a benefit to the economic, environment, and society (Govindan, Kannan, \& Shakar, 2014). Before, mining companies did not care about exploiting the land, and after using the area; they transferred to other areas to continue mining (Govindan, Kannan \& Shakar, 2014).

Mining companies had a problematic situation and due to the massive actions from the host and neighboring communities; mining industries embody sustainable practices as part of their business objectives. It is a fact that for a mining company to survive, it must adhere to sustainable development and responsible mining practices (Compliance \& Beyond, 2011). When CSR is now being introduced and mining company starts to integrate into their business model its helps to manage community relations properly. Multinational corporations make use of CSR in constituting global processes in local places, so their actions are creating, sustaining and reinforcing the local communities (Turker, 2018).

Though many positive views about CSR are available, there were findings of many researches about the weaknesses of CSR when it comes to implementation. CSR is good, but does it really impact the local community, or does it address the community development challenges (Wilson, 2015) In Ghana, mining firms do various CSR programs for the local community but have not converted to sustainable development due to persistence complains about social, environmental and economic backlash (Zamorshchikova 2016).

The expanding written works on the business industry is that social and economic benefits are suitable for profit. However, it is questionable if it's really impacted the community (Wilson, 
2015). It is a debate on many researches findings that CSR is not really a solution for addressing community development needs in the mining areas.

The negligence to manage disparity and methods present challenges moving forward to the number of studies and have shown that corporate investments in communities by mining companies result in corporate-controlled development instead of community-led development (Wilson, 2015). Diverse layers of authority may also weaken community development because of different point of views. Others insist that mining companies have the right to create public image and show that they are serious in accommodating social interests although their primary goal is to make money (Wilson, 2015). This kind of action weakens the real principles of CSR and community development and can definitely fail to reach its objectives (Wilson, 2015).

CSR may cause dependency rather than capacity if it is not aligned to the principles of people empowerment and sustainable development (Essah \& Andrews, 2016). Mining can only achieve sustainability if both parties get advantages. Social license to operate is mandatory for the mining companies; it is a major rope of corporate social responsibility (Owen \& Kemp, 2013). The idea of just getting the license to operate and not considering the public consent may affect its financial performance (Wilson, 2015). In Chile, they only focus on community board rather than the interest of the whole community and their projects are just short-term with low impact to the development of the host and neighbouring communities (Wilson, 2015).

\section{Social Impact Assessment and Sustainable Development}

Economic growth is associated with unintended negative effects on people and the environment. Those effects need to identify and measured to manage is such a way that positive benefits should translate equally to minimize negative externalities. Impact Assessment provides a significant approach to sustainable development (Momtaz and Kabir, 2018). Impact assessment is a thorough assessment of the possible or real impact of program on the economic, social and environmental dimension of a sustainable development (Momtaz and Kabir, 2018). Assessment should use both qualitative and quantitative data, the significance of an impact is used to determine its priority for mitigation. It is important to remember that impacts can be positive or negative and so may need development for community benefits rather than mitigation (Leading Practice to Sustainable Development Program for the Mining Industry, 2016).

Impact assessment in the context of Social Assessment (SA) is to ensure that development initiatives contribute to poverty alleviation, and at the same time enhance inclusion, increase social capital, build ownership, and eliminate or at least reduce adverse social impacts (World Bank, Social Assessment Guidelines, 1998). Bowles (1981) developed a useful approach to SIA by integrating it with community development, he focuses on key indicators of community life such as social vitality, viability of the local economy. This approach was further enhanced by Blishen et. al. in their Socio-Economic impact model (1979) focuses on three factors: 1. Economic factors 2. Community patterns of social behavior 3. The extent to which the economic factors and community social behavior are associated with the mobilization of political power or process. The model tried to give a more holistic view of the community and the encounter that constitute it (Helen Ross, 1990). 


\section{Mining and Community Conflict}

With the continued growth of the mining industry, the demand is greater so as to respond to the needs of globalization (Martinez Alier, 2001). The laws permitted to further develop mining (Conde \& Bilion, 2017). Along with the rise of the price of the mine products, an easy access to funds due to interest rates (Conde and Bilion, 2017).

Many mining companies go father to explore more and most of the time in the areas where there is a community, majority of them are indigenous, who experience adverse social impacts like displacement, pollution, and unequal power distribution, and discrimination, and violation of human rights, among others (Conde \& Bilion, 2017).

Lack of sufficient consultations and community engagement led to inaccuracy of information regarding mining impacts that serve as continuous problems. The conflict intensifies and the adverse impact caused by it is becoming more visible (Castells, 2013; Conde \& Bilion, 2017). Resistance from local communities is a big concern of the policy makers (Franks, et al., 2014; Gamu, et al., 2015) and particularly relevant in the molding community wilderness (Conde \& Kallis, 2012; Exner, et al., 2015; Le Billon and Sommerville, 2016). Then it became difficult to comprehend why resistance to mining continuously arises (Conde \& Kallis, 2012).

The concept of resistance can be defined to different forms of defiance and movements. Commonly showed a dominance perspective (Conde \& Bilion, 2017; Rose, 2002).

\section{Mining Industry and Poverty}

Mining companies are expected to contribute to the growth of the economy and alleviate poverty through the creation of jobs and opportunities, livelihood, access to health services, access to education and public services. However, a lot of researchers strive to connect the relationship of mining companies and development (Bebbington, et al., 2008; Gamu, et al., 2014). World Bank Group cautioned that mining companies in the third-world countries can contribute to poverty alleviation (Gamu, et al., 2014). Some mining companies in Chile, Ghana and Brazil have a distinct advantage in contributing to the lessening of the high levels of poverty and positive social development performance through their employment opportunities, local procurement, infrastructure and public services such as health, education and training through their corporate social responsibility (CSR) programs (Dashwood, 2012).

Mining companies, governments, international development agencies and communities present different perceptions regarding the potential impact of mining companies to poverty reduction, because of associated negative views from the past and present records of adverse impact to the environment and the communities together with corruption and conspiracy that was said to unlikely help the poor (Gamu, et al., 2014).

The "Resources Curse Model" (Auty, 1994, as cited in Canavesio, 2014) is a related concept. According to many scholars, for a long period of time, studies have seen a result of disagreement (Canavesio, 2014; Ross, 2003). An array of examples around the globe has shown that mining companies often create dispute, misconduct, weakening of the local society rather than poverty alleviation (Bebbington, et al., 2008; Pegg, 2006).

\section{Theoretical Framework}

Theory of Change - It is hard to follow decisively when the expression "Theory of Change" was first utilized, however an allude to its inceptions can be found in the impressive group of 
hypothetical and connected advancement in the assessment field, particularly among crafted by individuals, such as, Huey Chen, Peter Rossi, Michael Quinn Patton, and Carol Weiss. These assessment scholars and experts, alongside a large group of others, have been centered on how to apply program speculations to assessment for a long time (Center for Theory of Change). Wess (1995) highlights "Theory of Change" (TOC) is a method that explains how a given intervention, or set of interventions, is expected to make a specific development change, through analysis based on available evidence (UNDG, Theory of Change, 2018). Like the mandated social development of mining companies (SDMP) is a kind of intervention.

The theory of change definition suggests that the first step towards evaluating a program is to determine the intended outcomes (Connell and Kubisch, 1998).

The following are the reasons why theory of change best supports the study: (Center for Theory of Change, 2017)

1. Identifying long-term goals - determine intended outcome (SDMP objectives: responsible, self-reliant and resource-based community)

2. Backwards mapping and connecting outcomes- identify the "root" causes of the problem they hope to resolve (through series of dialogues and consultations)

3. Completing the outcomes framework - it is a precondition that this will be the outcome (emphasis on the objective of the SDMP)

4. Identifying Assumptions- continuously documenting assumptions and justifications. As outcomes are validated if this will apply and moved on the framework, and prove why it is necessary (can be tested through data analysis)

5. Developing Indicators- is significant to measure the impact and of the program. By collecting data on each outcome, whether it is positive or negative (combined indicators from different frameworks as well as actual experiences)

6. Identifying Interventions- By identifying interventions, the community demonstrates how their participation is going to change the community (what kind of interventions are consistent to the needs, interest and capacity of the community) 


\section{Research Framework}

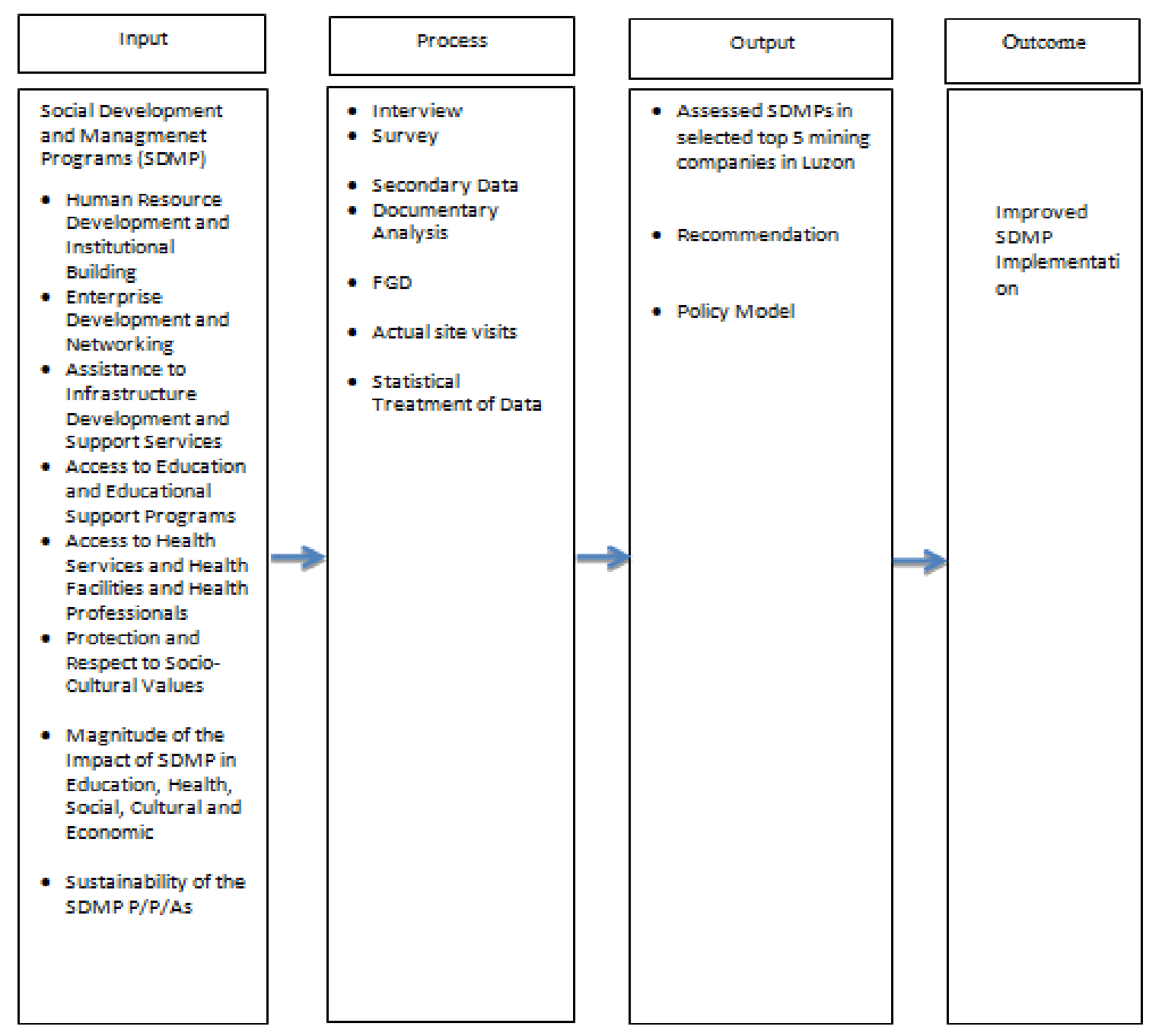

Figure 2: Conceptual Framework Model for the Mining Companies' Social Development and Management Program Implementation under CDAO 2010-21

Before any mining projects are given permits by the DENR, they should be: (1) technically feasible, (2) environmentally compliant, (3) socially acceptable, and (4) financially viable. If any of these imperatives is absent, then it is not time to mine. This was based on the Declaration of Policy of the Philippine Mining Act of 1995, which states: "It shall be the responsibility of the State to promote their rational exploration, development, utilization and conservation through the combined efforts of government and the private sector in order to enhance national growth in a way that effectively safeguards the environment and protect the rights of affected communities" (RA 7942).

\section{Research Methodology}

The study made us of both qualitative and quantitative research designs to assess the social development and management programs of the top five mining/quarrying companies in Luzon to help achieve the government's thrust of creating self-sustainable and resource-based local 
communities. The mixed-method approach design is aimed to achieve a fuller assessment of the SDMP for communities of the mining companies and to determine specific recommendations to contribute to the improvement of implementation and evaluation.

The sample size of 376 was obtained by using the simple random sampling technique referencing to Cochran's formula for calculating sample size when population is finite with $95 \%$ level of confidence and 5\% margin of error. The stratified proportional allocation using each community as the stratum was used to determine the number of households to be sampled for each mining site.

For the quantitative design, a self-made questionnaire which was tested for validity and reliability was used. On the other hand, for the qualitative method, the study used purposive sampling procedure to identify respondents from different sector in the barangay for the interview and convenience sampling of respondents from the community for the FGD.

\section{Results and Discussions}

The quantitative method was used to gather the data from the communities in the selected Large-Scale Mining/Quarrying in Luzon.

For objective number 1, to determine the awareness of the communities about the Social Development and Management Programs of mining companies in terms of the following accredited programs/projects/activities under the CDAO-2010-21
1.1 Human Resources Development
1.2 Enterprise Development
1.3 Assistance to Infrastructure Development
1.4 Access to Education
1.5 Access to Health Services
1.6 Protections and Respect of Socio-Cultural Values

Table 2: Percentage of Respondents from Each Barangay That Are Aware on The Current SDMPs Being Implemented in Their Community

\begin{tabular}{|c|c|c|c|c|c|c|c|c|}
\hline & $\begin{array}{c}\text { Bgy. Didipio } \\
\text { Nueva } \\
\text { Vizcaya }\end{array}$ & $\begin{array}{c}\text { Bgy. } \\
\text { Bayabas } \\
\text { Bulacan }\end{array}$ & $\begin{array}{c}\text { Bgy. } \\
\text { Matictic } \\
\text { Bulacan }\end{array}$ & $\begin{array}{c}\text { Bgy. } \\
\text { Minuyan } \\
\text { Bulacan }\end{array}$ & $\begin{array}{c}\text { Bgy. } \\
\text { San } \\
\text { Isidro } \\
\text { Rizal }\end{array}$ & $\begin{array}{c}\text { Bgy. } \\
\text { San } \\
\text { Roque } \\
\text { Rizal }\end{array}$ & $\begin{array}{c}\text { Bgy. } \\
\text { Camp } 3 \\
\text { Benguet }\end{array}$ & $\begin{array}{c}\text { Tuba, } \\
\text { Benguet }\end{array}$ \\
\hline \multicolumn{9}{|c|}{ 1. Human Resources Development } \\
\hline \multicolumn{9}{|c|}{ Capacity Building on: } \\
\hline $\begin{array}{l}\text { a. Project } \\
\text { Development }\end{array}$ & 100.0 & 40.0 & 76.5 & 100.0 & 53.2 & 69.1 & 57.1 & 80.0 \\
\hline $\begin{array}{l}\text { b. Organizational } \\
\text { Development }\end{array}$ & 28.6 & 40.0 & 76.5 & 100.0 & 53.2 & 66.7 & 100.0 & 100.0 \\
\hline $\begin{array}{l}\text { c. } \\
\text { Entrepreneurship }\end{array}$ & 9.5 & 40.0 & 97.1 & 74.1 & 31.9 & 15.8 & 100.0 & 100.0 \\
\hline Skills & 14.3 & 100.0 & 100.0 & 37.0 & 44.7 & 59.4 & 100.0 & 100.0 \\
\hline
\end{tabular}




\begin{tabular}{|c|c|c|c|c|c|c|c|c|c|}
\hline Development & & & & & & & & & \\
\hline 2. Enterprise Dev & lopme & and $N$ & prking & & & & & & \\
\hline Income Generating & Activit & & & & & & & & \\
\hline a. Animal & & & & & & & & & \\
\hline Husbandry & & 14.3 & 10.0 & 64.7 & 72.2 & 27.7 & 18.8 & 71.4 & 40.0 \\
\hline $\begin{array}{l}\text { b. Provision of } \\
\text { Farm Implements }\end{array}$ & 28.6 & & 10.0 & 85.3 & 66.7 & 23.4 & 23.6 & 62.9 & 90.0 \\
\hline $\begin{array}{l}\text { c. Establishment } \\
\text { of } \quad \text { Micro- } \\
\text { Businesses }\end{array}$ & 42.9 & & 60.0 & 94.1 & 68.5 & 17.0 & 7.3 & 25.7 & 20.0 \\
\hline $\begin{array}{l}\text { d. Cooperative } \\
\text { Development }\end{array}$ & 61.9 & & 100.0 & 100.0 & 55.6 & 23.4 & 13.3 & 45.7 & 10.0 \\
\hline $\begin{array}{lr}\text { e. } & \text { Market } \\
\text { linkages } & \text { and } \\
\text { networking } & \end{array}$ & 61.9 & & 0.0 & 38.2 & 11.1 & 17.0 & 10.9 & 54.3 & 10.0 \\
\hline 3. Assistance to In & rastru & Dre & nment & Suppo & rvices & & & & \\
\hline $\begin{array}{l}\text { Stimulating and } \mathrm{Fa} \\
\text { and maintenance } \mathrm{o}\end{array}$ & ilitatin & ther $\mathrm{f}$ & of Ecc & iic Acti & such as & velopr & t, cons & on, im & rement \\
\hline $\begin{array}{l}\text { a. Farm-to-market } \\
\text { roads }\end{array}$ & 76.2 & & 60.0 & 44.1 & 31.5 & 31.9 & 34.5 & 45.7 & 30.0 \\
\hline b. Water systems & 61.9 & & 80.0 & 50.0 & 20.4 & 29.8 & 28.5 & 45.7 & 40.0 \\
\hline $\begin{array}{l}\text { c. Post-harvest } \\
\text { facilities }\end{array}$ & 66.7 & & 10.0 & 100.0 & 27.8 & 29.8 & 26.7 & 77.1 & 80.0 \\
\hline d. Bridges & 71.4 & & 10.0 & 100.0 & 0.0 & 34.0 & 24.2 & 80.0 & 100.0 \\
\hline e. Electricity & 47.6 & & 60.0 & 50.0 & 55.6 & 48.9 & 49.7 & 77.1 & 100.0 \\
\hline 4. Access to Educ & tion ar & Educa & al Sup & Progra & & & & & \\
\hline Providing Educatic & hal opp & tunities & & & & & & & \\
\hline $\begin{array}{l}\text { a. Scholarship } \\
\text { from primary to } \\
\text { tertiary education }\end{array}$ & 61.9 & & 100.0 & 100.0 & 98.1 & 42.6 & 34.5 & 82.9 & 100.0 \\
\hline $\begin{array}{l}\text { b. Provision of } \\
\text { apprenticeship } \\
\text { programs }\end{array}$ & 23.8 & & 0.0 & 67.6 & 1.9 & 25.5 & 13.9 & 91.4 & 100.0 \\
\hline $\begin{array}{l}\text { c. Construction } \\
\text { and Repair of } \\
\text { school buildings }\end{array}$ & 28.6 & & 30.0 & 100.0 & 98.1 & 31.9 & 22.4 & 71.4 & 60.0 \\
\hline $\begin{array}{ll}\text { d. Subsidy for } \\
\text { Teachers }\end{array}$ & 42.9 & & 0.0 & 0.0 & 1.9 & 40.4 & 44.2 & 60.0 & 80.0 \\
\hline
\end{tabular}




\begin{tabular}{|c|c|c|c|c|c|c|c|c|}
\hline \multicolumn{9}{|c|}{ 5. Access to Health Services, Facilities and professionals } \\
\hline \multicolumn{9}{|c|}{ Improving the living Conditions and Health } \\
\hline $\begin{array}{l}\text { a. Provision of } \\
\text { health facilities }\end{array}$ & 28.6 & 0.0 & 100.0 & 100.0 & 68.1 & 78.2 & 74.3 & 80.0 \\
\hline $\begin{array}{l}\text { b. Access to } \\
\text { health services, } \\
\text { medicines and } \\
\text { professionals }\end{array}$ & 38.1 & 10.0 & 100.0 & 100.0 & 51.1 & 63.6 & 51.4 & 70.0 \\
\hline $\begin{array}{lr}\text { c. Health } \\
\text { education and } \\
\text { preventive } \\
\text { measures training }\end{array}$ & 57.1 & 10.0 & 100.0 & 98.1 & 23.4 & 27.3 & 74.3 & 90.0 \\
\hline $\begin{array}{l}\text { d. Provision of } \\
\text { health insurance }\end{array}$ & 71.4 & 0.0 & 0.0 & 1.9 & 36.2 & 45.5 & 68.6 & 90.0 \\
\hline $\begin{array}{l}\text { e. Access to clean } \\
\text { and potable water }\end{array}$ & 81.0 & 50.0 & 100.0 & 50.0 & 31.9 & 42.4 & 45.7 & 60.0 \\
\hline $\begin{array}{l}\text { f. Provision of } \\
\text { waste and sewage } \\
\text { disposal facilities }\end{array}$ & 76.2 & 10.0 & 50.0 & 42.6 & 40.4 & 55.2 & 71.4 & 30.0 \\
\hline \multicolumn{9}{|c|}{ 6. Protection and Respect of Socio-Cultural Values } \\
\hline \multicolumn{9}{|c|}{ Safeguarding the Existing Socio-Cultural Values } \\
\hline $\begin{array}{l}\text { a. Special funding } \\
\text { for religious } \\
\text { activities }\end{array}$ & 81.0 & 10.0 & 38.2 & 44.4 & 53.2 & 72.7 & 94.3 & 40.0 \\
\hline $\begin{array}{l}\text { b. Promotion of } \\
\text { Cultural } \\
\text { Awareness }\end{array}$ & 57.1 & 20.0 & 23.5 & 22.2 & 61.7 & 58.8 & 88.6 & 80.0 \\
\hline
\end{tabular}

***The percentages were obtained from getting the proportion of the respondents who answered "Yes" against the total sample of the barangay.

Based from the percentage of awareness of the respondents on the SDMPs being implemented in their community, it can be observed that Barangay San Roque and San Isidro of Antipolo City, Rizal, and Barangay Bayabas of Bulacan were observed to have relatively low SDMPs being implemented in their community. For the Human Resources programs, barangays from Bulacan and Benguet showed high level of awareness from respondents on the SDMPs implemented. 
Table 3: Summary Statistics for the Implementation and Impact Module by Demographic Profile

\begin{tabular}{|c|c|c|}
\hline & $\begin{array}{c}\text { Average } \\
\text { Implementation } \\
\text { Dissatisfaction Score }\end{array}$ & $\begin{array}{c}\text { Average Impact } \\
\text { Dissatisfaction Score }\end{array}$ \\
\hline \multicolumn{3}{|l|}{ By Province } \\
\hline Benguet & 3.91 & 3.86 \\
\hline Bulacan & 29.08 & 16.34 \\
\hline Nueva Vizcaya & 3.69 & 3.45 \\
\hline Rizal & 28.01 & 3.50 \\
\hline \multicolumn{3}{|l|}{ By Age Group } \\
\hline 18 below & 24.75 & 3.25 \\
\hline $18-24$ & 27.33 & 7.93 \\
\hline $25-39$ & 25.30 & 7.63 \\
\hline $40-60$ & 24.79 & 6.99 \\
\hline 60 above & 17.61 & 4.39 \\
\hline \multicolumn{3}{|l|}{ By Sex } \\
\hline Male & 13.66 & 11.52 \\
\hline Female & 26.20 & 6.31 \\
\hline \multicolumn{3}{|l|}{ By Civil Status } \\
\hline Single & 27.43 & 4.47 \\
\hline Married & 23.78 & 6.19 \\
\hline Divorce & 22.32 & 20.41 \\
\hline Separated & 28.97 & 10.55 \\
\hline Widowed & 20.44 & 5.85 \\
\hline \multicolumn{3}{|c|}{ By Educational Level } \\
\hline Elementary Grad & 22.22 & 5.66 \\
\hline High School Grad & 27.95 & 8.27 \\
\hline College Undergrad & 24.25 & 8.56 \\
\hline College Grad & 27.35 & 8.55 \\
\hline Graduate School & 32.80 & 4.00 \\
\hline
\end{tabular}




\begin{tabular}{|l|r|r|} 
None & 26.19 & 5.85 \\
\hline Government & 21.86 & 11.00 \\
\hline Private & 21.79 & 9.38 \\
\hline Own Business & 11.90 & 12.19 \\
\hline By Monthly Income & \multicolumn{2}{|c|}{} \\
\hline 5,000 and below & 26.52 & 6.62 \\
\hline $6,000-10,000$ & 21.84 & 7.90 \\
\hline $11,000-15,000$ & 18.19 & 10.33 \\
\hline $16,000-20,000$ & & \\
\hline 21,000 and above & 3.40 & 2.50 \\
\hline By Number of Years in Residency & & 3.27 \\
\hline Less than a year & 7.73 & 5.30 \\
\hline $2-5$ & 23.78 & 6.43 \\
\hline $6-10$ & 25.30 & 8.29 \\
\hline $11-15$ & 24.22 & 7.08 \\
\hline Greater than 16 & 25.92 & \\
\hline
\end{tabular}

It can be observed that the average dissatisfaction scores on the implementation of SDMPs in their respective communities was relatively high for Bulacan and Rizal. Further, Bulacan also obtained the highest dissatisfaction score on the impact of SDMPs in their communities.

Also, the level of dissatisfaction on the implementation and impact of SDMPs from the respondents appeared to be not significant among age group.

It was also observed that female respondents tend to have a higher dissatisfaction rate on the implementation of SDMPs in their community. Meanwhile, male respondents see that SDMPs have little to no impact in the community.

There was no significant difference on the average dissatisfaction scores of the respondent my civil status.

It can also be observed that the dissatisfaction rate of the respondents on the implementation and impact of SDMPs decreases as the income increases.

For objective number 2 which is to measure the impact of Social Development and Management Programs to the following aspects:

2.1 Education

2.2 Health

2.3 Social and Cultural

2.4 Economic 
The implementation of the SDMP should have a positive impact to the communities mentioned so as the budget allotted there is not wasted. The objective of the Program is to effect positive changes and uplift the general welfare and well being of the same. So in the interview with the respondents in terms of Educational Assistance, the mining companies have contributed since they were able to help some of the community members to graduate, although according to some respondents, there were only limited slots under the scholarship program.

In terms of the Health Support, all of the respondents said that there were medicines provided but limited to basic medicines which are not enough to support the communities. In terms of the Socio-Cultural, all respondents said that the SDMP supported cultural preservation activities like fiestas and other traditional celebrations. The poverty rate level in all barangays had decreased and the corresponding employment had increased. However, problems in electricity and water supplies are the issues in Barangay Didipio and in the municipality of Benguet; Lastly, in terms of the economic aspect, many cooperatives were established except in Barangay Matictic wherein all of the cooperatives closed down because of mismanagement.

Lastly, for objective number 3 which is to ascertain the sustainability of the Social Development and Management Programs of the mining companies in terms of:

3.1 Stakeholders Groups Relationship

3.2. Company Financial and Management Capacity

3.3 Compliance with the legal requirements

This is the crucial part of the program process pertained to sustainability to continue and pursue it despite the challenges it faced every day. It still needs to identify why some social issues in the communities are still not properly address. Also, is the funding enough to sustain the program? This is one element of mismanagement skills, which leads to another corruption.

According to all respondents all of the companies have established stakeholder groups' relationship because they have been granted the necessary mining permits in order to proceed to the extraction of the minerals in the locations. It has been identified that consultations in Local Government Units and Members of different sectors were conducted as an initial requirements and compliance to gained social license to operate and continuously consulting while the operation is ongoing.

According to the respondents that during the SDMP implementation, as required by the law the sectors of the communities where the SDMP is developed were involved and that their actual needs and interests are the basis for the identification of the programs/projects/activities (P/P/As) of the SDMP.

All the respondents agreed that mining companies are financially capable of implementing Social Development Programs. However, majority of the respondents said if the mining companies could increase the $1.5 \%$ budged for social development programs because not all proposed programs, projects and activities, which they think, are much needed in the communities was left and ignored. In terms of the mining companies community relation officers, according to the respondents the companies have enough team however some of 
them do not possess the required qualifications because some comrel is an I.T. graduate and engineers.

The national government is rigorously implementing the Philippine mining law to all companies. The Law clearly stated that the said companies should support the host and neighbouring communities through its Social Development and Management Program (SDMP) and assist in the general development of the same and make them self sustainable and empowered. This is based on the people centered theory by Rogers 1987 stating that in order for a community to become sustainable the people must be at the center of development. The said companies implemented the P/P/As as indicated in the results of the survey and interviews conducted but it is noted that not all community residents benefit from it only selected people are aware that there are programs/projects/activities implemented in their community. The objective of the Law is to mandate the companies to implement the Program to the communities where the Project is located. The companies reflect in their implementation the relative lack of information dissemination and encouragement to all members of the community. It is hard to achieve the objective of the SDMP if not all members of the community are a part of the P/P/As of the SDMP because one of the significant element of community development is the participation of the community members from the first stage up to the last part of the social programs/projects/activities (Nwapi, 2014; Cavaye, 2015). From the observation the lack of social licence to operate is the problem similar to the original article "Meeting the Local needs in South Africa by Wahlberg et al 2017, there were communities that did not fully support the mining companies operations despite the efforts made to support the identified needs of the same. Some people in the communities showed no interest at all. Further, the aims of the Social Development and Management Program (SDMP) is to reduce poverty by creating a responsible, self-reliant and resource based communities that are capable of developing, implementing and managing their own especially when the mine already ceased its operations and that is clealy stated in the Philippine Mining Law, and its already in place in many countries (Dupuy, 2014) however, the challenge to the countries that adopted community development into their mining law is the impact of the implementation. According to Rodrigues and Mendez, 2017 in their article "

A systematic Review on Social Responsibility in the Mining Industry that corporate social responsibility has little impact to the poverty reduction it is only associated to minor contribution to the community because mining companies has often linked to a broken promise concerning educational, health, social, cultural and economic development. Which was proven in this study that there is a little impact to the community development although infrastructure has the highest budget allocation. From the majority to selected respondents both have the same answers. It is important that any kind of intervention like social development programs of mining companies make a development change (Theory of Change, 2018). No matter how big or small the budget but proper implementation of the Programs/Projects/Activites could make a lot of changes in the community. The time spent by the mining companies in the community should have given appropriate return since the mining will surely cease its operation. Also, according to the study about Extractive industries and poverty entitled "A Review of Recent Findings and Linkage Mechanisms" by J. Gamu, et al. (2015), there is a lack of uniformity with regard to the extent of contribution of mining companies to reduce poverty. It proved that large-scale mining companies contribute to the reduction of poverty (Gamu, et al., 2015). However, cross national studies have found that poverty increased rather than decreased because of unfair practices (Gamu, et al., 2015). Subsequent research using panel data other than cross-sectional data (Davis \& Cordano, 
2013) found no measured significance whether in the reduced or increased correlation between mining and poverty (Gamu, et. al., 2015).

\section{Conclusions}

The following conclusions were derived from the quantitative data:

1. Based from the percentage of awareness of the respondents on the SDMPs being implemented in their community, it can be observed that Barangay San Roque and San Isidro of Antipolo City, Rizal, and Barangay Bayabas of Bulacan were observed to have relatively low SDMPs being implemented in their community. For the Human Resources programs, barangays from Bulacan and Benguet showed high level of awareness from respondents on the SDMPs implemented.

2. It can be observed that the average dissatisfaction scores on the implementation of SDMPs in their respective communities was relatively high for Bulacan and Rizal. Further, Bulacan also obtained the highest dissatisfaction score on the impact of SDMPs in their communities.

3. It was also observed that female respondents tend to have a higher dissatisfaction rate on the implementation of SDMPs in their community. Meanwhile, male respondents see that SDMPs have little to no impact in the community.

On the other hand, for the qualitative data, the following conclusions were obtained:

1. The Large-Scale Mining Companies has implemented Programs/Projects/Activites in their host communities. However, to some selected people only. Majority of the respondents have limited knowledge about SDMP.

2. On the impact of the SDMP to the community, it was observed that it has a weak impact especially in supporting the Health Aspect.

3. When it comes to sustainability of the SDMP, company is financially capable, however there were issues raised against them that mining companies are lack of community relations that lead to low interest of the community to join them.

4. When it comes to adherence to the legal requirements, there were gaps found in this research like no proper documents given to the barangay and the sector that suppose to be submitted for check and balance.

5. There were lack of monitoring and evaluation of the programs/projects/activities.

\section{References}

Bebbington, A. J., Bury, J., Humphreys Bebbington, D., Lingan, J., Muñoz, J. P., \& Scurrah, M. (2008). Mining and Social Movements: Struggles over Livelihood and Rural Territorial Development in the Andes. SSRN Electronic Journal. doi:10.2139/ssrn.1265582

Canavesio, R. (2014). Formal mining investments and artisanal mining in southern Madagascar: Effects of spontaneous reactions and adjustment policies on poverty alleviation. Land Use Policy 36, 145-154. doi: 10.1016/j.landusepol.2013.08.001

Conde, M., \& Le Billon, P. (2017). Why do some communities resist mining projects while others do not? The Extractive Industries and Society, 4(3), 681-697. doi: 10.1016/j.exis.2017.04.009

Dashwood, H. S. (2015). Sustainable Development Norms and CSR in the Global Mining Sector. Governance Ecosystems. doi:10.1057/9780230353282.0009

DENR (MINES AND GEOSCIENCES BUREAU. (2018). Mining and geosciences bureau heighten awareness on programs and responsible mining practices in the Philippines. Retrieved from MGB website: http://www.mgb.gov.ph/2015-05-13-02-02-11/mgb- 
news/601-mgb-heightens-awareness-on-programs-and-responsible-mining-practicesin-the-ph

DENR CONSOLIDATED ADMINISTRATIVE ORDER. (2010). PROVIDING FOR A CONSOLIDATED DEPARTMENT OF ENVIRONMENT AND NATURAL RESOURCES ADMINISTRATIVE ORDER FOR THE IMPLEMENTING RULES AND REGULATIONS OF REPUBLIC ACT NO. 7942, OTHERWISE KNOWN AS THE "PHILIPPINE MINING ACT OF 1995". Retrieved from DENR-MGB website: http://www.mgb.gov.ph/images/stories/CDAO-Final.pdf

Department of Environment and Natural Resources Mines and Geosciences Bureau, Mining Environment and Safety Division. (n.d.). SDMP Procedural Guidelines. Diliman, Quezon City, Philippines: DENR.

ICC 2005 IEEE International Conference on Communications. (2005). IEEE International Conference on Communications, 2005. ICC 2005. 2005. doi:10.1109/icc.2005.1494283

Dupuy, K. E. (2014). Community development requirements in mining laws. The Extractive Industries and Society, 1(2), 200-215. doi: 10.1016/j.exis.2014.04.007

Editor's Comments. (2004). Community Development Society. Journal, 34(2), i-ii. doi:10.1080/15575330409490109

Essah, M., \& Andrews, N. (2016). Linking or de-linking sustainable mining practices and corporate social responsibility? Insights from Ghana. Resources Policy, 50, 75-85. doi: 10.1016/j.resourpol.2016.08.008

Exner, A., Lauk, C., \& Zittel, W. (2014). Sold Futures? The Global Availability of Metals and Economic Growth at the Peripheries: Distribution and Regulation in a Degrowth Perspective. Antipode, 47(2), 342-359. doi:10.1111/anti.12107

Fraser, J. (2018). Mining companies and communities: Collaborative approaches to reduce social risk and advance sustainable development. Resources Policy. doi: 10.1016/j.resourpol.2018.02.003

George, G., Howard-Grenville, J., Joshi, A., \& Tihanyi, L. (2016). Understanding and Tackling Societal Grand Challenges through Management Research. Academy of Management Journal, 59(6), 1880-1895 doi:10.5465/amj.2016.4007

Govindan, K., Kannan, D., \& Shankar, K. M. (2014). Evaluating the drivers of corporate social responsibility in the mining industry with multi-criteria approach: A multistakeholder perspective. Journal of Cleaner Production, 84, 214-232. doi: 10.1016/j.jclepro.2013.12.065

Katrin \& Kehrbach. (2014). The mining industry is viewed as a major contributor to the country's fortune.

Kemp, D., Owen, J. R., \& Van de Graaff, S. (2013). Corporate social responsibility, mining and "audit culture". Journal of Cleaner Production, 24, 1-10. doi: 10.1016/j.jclepro.2011.11.002

Le Billon, P., \& Sommerville, M. (2017). Landing capital and assembling 'investable land' in the extractive and agricultural sectors. Geoforum, 82, 212-224. doi: 10.1016/j.geoforum.2016.08.011

Martinez-Alier, J. (2001). Mining conflicts, environmental justice, and valuation. Journal of Hazardous Materials, 86(1-3), 153-170. doi:10.1016/s0304-3894(01)00252-7

MOMTAZ, S. A. (2018). EVALUATING ENVIRONMENTAL AND SOCIAL IMPACT ASSESSMENT IN DEVELOPING COUNTRIES. S.1.: ELSEVIER.

Momtaz, S., \& Kabir, Z. (2018). Evaluating environmental and social impact assessment in developing countries. 
Nwapi, C. (2014). Enhancing the Effectiveness of Transparency in Extractive Resource Governance: A Nigerian Case Study. Law and Development Review, 7(1). doi:10.1515/ldr-2014-0015

Pegg, S. (2006). Mining and poverty reduction: Transforming rhetoric into reality. Journal of Cleaner Production 14(3-4), 376387.doi: 10.1016/j.jclepro.2004.06.006

Pimentel, B. S., Gonzalez, E. S., \& Barbosa, G. N. (2016). Decision-support models for sustainable mining networks: fundamentals and challenges. Journal of Cleaner Production, 112, 2145-2157. doi: 10.1016/j.jclepro.2015.09.023

Turker, D. (2018). Global Challenges: Aligning Social Responsibility and Sustainable Development Goals. CSR, Sustainability, Ethics \& Governance, 161-176. doi:10.1007/978-3-319-91710-8_10

Wilson, S. A. (2015). Corporate social responsibility and power relations: Impediments to community development in post-war Sierra Leone diamond and rutile mining areas. The Extractive Industries and Society, 2(4), 704-713. doi: 10.1016/j.exis.2015.09.002

Zamorshchikova, V. (2016). MINING AND INDIGENOUS COMMUNITIES: CSR PRACTICES OF MINING COMPANIES. 16th International Multidisciplinary Scientific GeoConference SGEM2016, Science and Technologies in Geology, Exploration and Mining. doi:10.5593/sgem2016/b12/s03.077

Zvarivadza, T. (2017). Large scale miners - Communities partnerships: A plausible option for communities' survival beyond mine closure. Resources Policy. doi: 10.1016/j.resourpol.2017.12.005

Zhou, Y., Guo, Y., Liu, Y., Wu, W., \& Li, Y. (2018). Targeted poverty alleviation and land policy innovation: Some practice and policy implications from China. Land Use Policy, 74, 53-65. doi: 10.1016/j.landusepol.2017.04.037 